PRINT ISSN 1119-8362

Electronic ISSN 1119-8362
Full-text Available Online at https://www.ajol.info/index.php/jasem http://ww.bioline.org.br/ja
J. Appl. Sci. Environ. Manage.

Vol. 25 (8) 1345-1348 August 2021

\title{
Isolation and Characterization of Photorhabdus Spp. (Enterobacteriaceae) Isolated From Heterorhabditis Bacteriophora in Kashere, Nigeria
}

\author{
${ }^{* 1,2}$ ALIYU, HU; ${ }^{2}$ TAHIR, F; ${ }^{2}$ AGBO, EB; ${ }^{1}$ KELA, SL \\ ${ }^{*}$ Department of Biological Sciences, Faculty of Science, Federal University of Kashere, P.M.B. 0182, Gombe State, Nigeria \\ ${ }^{2}$ Department of Microbiology, Faculty of Science, Abubakar Tafawa Balewa University, Bauchi, Nigeria \\ *Corresponding Author Email: habusman71@gmail.com; Tel: +2348034385031
}

\begin{abstract}
Photorhabdus bacteria are symbiotically associated with the infective juveniles of entomopathogenic nematodes of the genus Heterorhabditis. These bacteria after infecting a susceptible host, produces a host of lethal toxins that killthe insect hosts within 24 to 72 hours. Consequently they have emerged and are trending as excellent biological control agents against insect pests of agricultural crops. Therefore, this study aim to isolate, identify and test the pathogenicity of Photorhabdus bacteria isolated from Heterorhabditis bacteriophora, entomopathogenic nematode from Kashere, Gombe State, Nigeria. To this end phenotypic and biochemical tests were conducted. The tests conducted showed that the isolate exhibited characteristics similar to those of Photorhabdus bacteria that have been identified. Last instar larvae of G. mellonella exposed to different concentrations of the bacterial isolate showed some level of susceptibility of the larvae to the bacterial isolate confirming its biological control potential.
\end{abstract}

\section{DOI:https://dx.doi.org/10.4314/jasem.v25i8.9}

Copyright: Copyright $(0) 2021$ Aliyu et al. This is an open access article distributed under the Creative Commons Attribution License (CCL), which permits unrestricted use, distribution, and reproduction in any medium, provided the original work is properly cited.

Dates: Received: 10 May 2021; Revised: 28 June 2021; Accepted: 01 July 2021

Keywords: Photorhabdus bacteria, entomopathogenic biological control, Galleriamellonella, Kashere.

Photorhabdus species of bacteria are excellent candidates for the biological control of insect pests of agricultural crops. They have emerged as excellent alternatives to synthetic pesticides for the successful control of insect pests of agricultural crops worldwide Gaugler, 2002; Adams, 2006; Aliyu et al., (2015). They have been characterized as non-spore producing, Gram-negative, facultative anaerobic motile rods Owuama, 2001; Saenz-Aponte et al., (2014). These bacteria according to the report of Ferraira et al., (2013), are oxidase positive. They live in the intestinal lumen of infective juveniles of Heterorhaditis bacteriophora. The relationship between the bacteria and the nematode is symbiotic. The nematode is dependent upon the bacteria for killing the host insect, creating a suitable environment for the development of the nematode, breaking down the hosts' tissues into utilizable nutrients and serving as a food source. The nematode protects the bacteria from the external environment since the bacterium is unable to survive living freely. The nematode acts as a vector, penetrates the host and regurgitates its symbiotic bacteria into the haemocoel of the host insect Hinchliffe et al., (2010). Thebacteria produce a spectrum of toxins and antibiotics Hinchliffe et al., 2010; Lang et al., (2014) which inhibit potential competitors Orozco et al., (2013). The bacteria proliferate and provide nutrition for the developing nematodes Webster et al., (2002). The multiplication of the Photorhabdus bacteria leads to septicemia and toxemia and eventual death of the insect host within 48-72 hrs Saenz-Aponte et al., (2014). About three species of Photorhabdus have been classified thus; $P$. luminescens Thomas and Poinar, P. temperate Fischer-Le Saux, $P$. asymbiotica Akhurst and seven subspecies have been described specifically for $P$. luminescens Saenz-Aponte et al., (2014). The characterization and identification of these species and sub-species have been achieved by the use of morphological, biochemical as well as molecular characteristics as reported by Saenz-Aponte et al., (2014). Though studies have been conducted on the exploitation of nematode-bacteria complex as potential biological pesticides against local pests of crops, similar study have not been reported in Kashere. Therefore, this study aim to isolate, identify and test the pathogenicity of Photorhabdus bacteria isolated from $H$. bacteriophora entomo-pathogenic nematode from Kashere in Nigeria

\section{MATERIALS AND METHODS}

Isolation and culture of symbiotic bacteria: Entomopathogenic nematodes were isolated from soil samples collected in Kashere using an established Galleria mellonella L. (Lepidoptera: pyralidae) bait 
method and the white trap. The entomopathogenic nematodes were characterized and identified as Heterorhabditis bacteriophoraAliyu et al., (2019). Dead larvae of Galleria mellonella infected 48h earlier with infective juveniles of $H$. bacteriophora were surface sterilized in $70 \%$ alcohol for 10 mins. The larvae were allowed to dry and a fore limb was removed with a sterile scissors. Using a sterile wireloop, a drop of oozing hemolymph from each larva was inoculated on to nutrient agar, nutrient agar bromothymol blue and MacConkey agar plates. The plates were incubated at $32^{\circ} \mathrm{C}$ for $48-72 \mathrm{hrs}$. Single colonies were picked with a sterile wire loop and subcultured twice to obtain a pure culture which was used for this study. The bacterial isolates were sub cultured on nutrient agar slants for storage Emeliahoff et al., (2008).

Phenotypic and biochemical characterization of bacterial symbionts:Colony pigmentation, shape and size were examined on nutrient agar, MacConkey (Oxoid) and Nutrient agar bromothymol blue plates after $72 \mathrm{~h}$ of incubation at $32^{\circ} \mathrm{C}$. The light microscope was used to observe the isolates after Gram staining. The biochemical tests carried out included; production of acid from carbohydrates, citrate, indole production after $48 \mathrm{~h}$, catalase and oxidase activities were also evaluated. Lecithinase, protease and lipolytic activity were carried out on egg yolk agar Jang et al., (2011).

Pathogenicity test of the bacterial isolate on $G$. mellonellla:Pasteur pipettewas used to transfer $0.5 \mathrm{ml}$ of $0,10^{-2}, 10^{-4}$ and $10^{-6}$ cells $/ \mathrm{ml}$ of the bacterial isolate to the feed of larvae of $G$. mellonellawhich was thoroughly mixed. Three replicates of the experimental design were used and five larvae each were introduced into each concentration per unit. The containers were kept in a dark cupboard at room temperature and observed daily for mortality during 5 days.

Similarly a drop of oozing hemolymph from dead $G$. mellonellla larvae was extracted and cultured on MacConKey, NBTA and Nutrient agar to verify that the bacteria isolate was responsible for the death of the larvae. Statistical analysis was done using ANOVA to determine the effect of the concentrations of the bacterial isolates on the larvae of G. mellonellla Jang et al., (2011).

\section{RESULTS AND DISCUSSION}

Phenotypic and Biochemical characterization of bacterial endosymbionts: The colonies absorbed dye on MacConkeyand NBTA plates. On MacConkey agar colonies absorbed neutral red dye and appeared pink and mucoid, (a) on nutrient agar they appeared milky white and shiny (b) while on nutrient bromothymol blue NBTA plates colonies absorbed the blue colour of the dye and appeared dark bluish-green (c).At $72 \mathrm{~h}$ of incubation, distinct colonies on NBTA appeared convex, small and $1 \mathrm{~mm}$ in size.

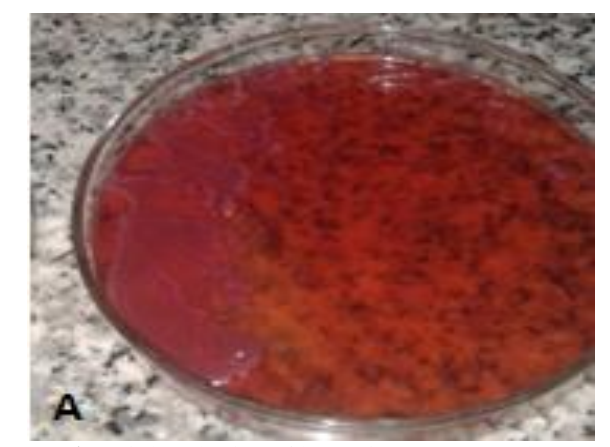

Plate 1c: Pink colonies of bacteria on MacConkey agar

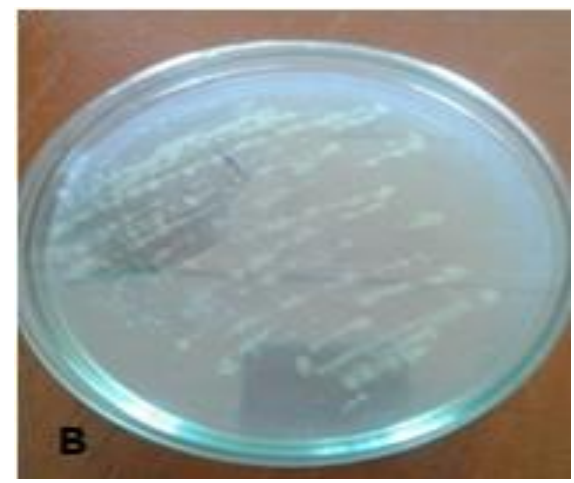

Plate 1b: Milky white colonies on nutrient agar

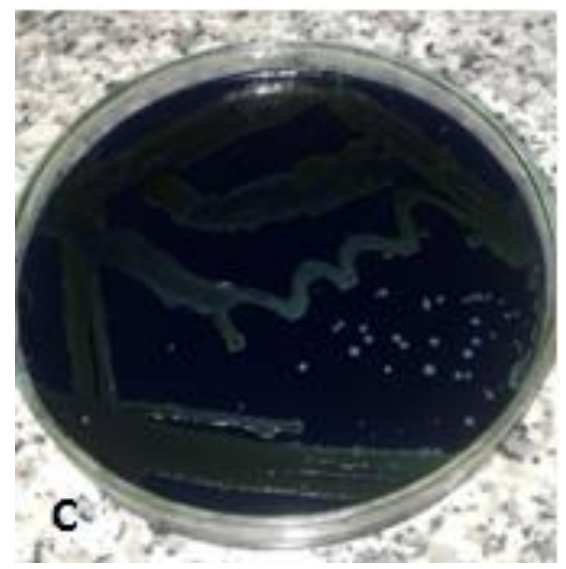

Plate 1c: Bluish-green colonies on nutrient agar bromothymol blue (NBTA)

After Gram staining, cells of the bacterial isolateappeared as Gram-negative rods. From results of the biochemical tests, the bacterial isolate was able to ferment xylose, glucose, mannose and fructose as sources of carbohydrates, it was citrate positive, indole positive, oxidase positive as well as catalase positive. Lecithinase, protease and lypolytic activities were all negative. 
Pathogenicity test of the bacterial isolate on $G$. mellonella: Pathogenicity tests showed that the bacterial isolate was effective against the larvae of $G$. mellonella at various concentrations, however, variations were observed Table 1 and Figure 1 . The effect of $10^{2} \mathrm{CFU} / \mathrm{ml}$ of the isolate commenced $48 \mathrm{~h}$ after exposure to $G$. mellonella and was slower at killing the larvae whereas concentrations of $10^{4}$ and
$10^{6} \mathrm{CFU} / \mathrm{ml}$ of the isolate was effective at $24 \mathrm{~h}$ with $10^{6} \mathrm{CFU} / \mathrm{ml}$ killing all exposed larvae within $48 \mathrm{~h}$. The control had no effect on the larvae of $G$. mellonella. Results of ANOVA showed that there was a significant difference between the means of the concentrations of the isolate against the larvae of $G$. mellonella.

Table 1.Mean Mortality/day of Galleria mellonella larvae

\begin{tabular}{llllll}
\multicolumn{7}{c}{ Mortality/day of G. mellonella larvae } \\
\hline Concentration (CFU/ml) & $\mathbf{1}$ & $\mathbf{2}$ & $\mathbf{3}$ & $\mathbf{4}$ & $\mathbf{5}$ \\
\hline 0 & $0.00 \pm 0.00^{\mathrm{a}}$ & $0.00 \pm 0.00^{\mathrm{a}}$ & $0.00 \pm 0.00^{\mathrm{a}}$ & $0.00 \pm 0.00^{\mathrm{a}}$ & $0.00 \pm 0.00^{\mathrm{a}}$ \\
$10^{2}$ & $0.00 \pm 0.00^{\mathrm{a}}$ & $0.67 \pm 0.58^{\mathrm{a}}$ & $1.67 \pm 0.58^{\mathrm{b}}$ & $1.67 \pm 0.58^{\mathrm{b}}$ & $1.00 \pm 0.58^{\mathrm{b}}$ \\
$10^{4}$ & $0.33 \pm 0.58^{\mathrm{a}}$ & $1.67 \pm 0.58^{\mathrm{b}}$ & $2.33 \pm 0.58^{\mathrm{b}}$ & $0.67 \pm 0.58^{\mathrm{a}}$ & $0.00 \pm 0.00^{\mathrm{a}}$ \\
$10^{6}$ & $1.67 \pm 0.58^{\mathrm{b}}$ & $3.33 \pm 0.58^{\mathrm{c}}$ & $0.00 \pm 0.58^{\mathrm{a}}$ & $0.00 \pm 0.00^{\mathrm{a}}$ & $0.00 \pm 0.00^{\mathrm{a}}$ \\
\hline \multicolumn{5}{c}{ Mean \pm Standard Deviation (SD).Means with different superscript across the column differ significantly. }
\end{tabular}

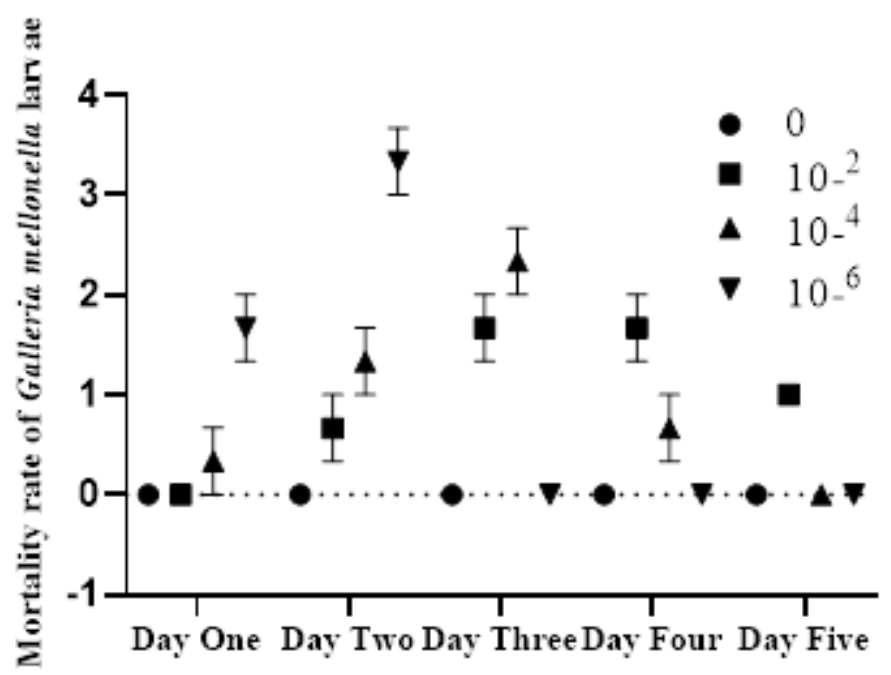

Number of days

Fig. 1. Mortality rate of G. mellonella larvae exposed to different concentrations of bacteria

Pigmentation of colonies is attributed to the ability of Photorhabdus bacteria to produce diffusible pigments, a characteristic similar to all described species of the genus Photorhabdus Saenz-Aponte et al., (2014). They absorbed neutral red on MacConkey and bromothymol blue on NBTA respectively as shown in plates (a) and (c) above. These properties are similar to those of Photorhabdus bacteria described by EunKung et al., 2012; Orozco et al., (2013). Bacterialisolates obtained from Heterorhabditis bacteriophora nematode presented a Gram-negative cell morphology which is characteristic of Photorhabdus sp. this observation is similar to that observed by Boemare and Akhurst 2006; SaenzAponte et al., (2014). Furthermore, the isolate like all species of described Photorhabdusbacteria are shiny after $48 \mathrm{~h}$ of incubation, a characteristic also observed by sing et al., (2012).The luminescence and morphological characters exhibited by the isolate confirms that the isolate is part of the genus Photorhabdus. Like described species, the isolate was able to ferment xylose, glucose, mannose and fructose as sources of carbohydrates which shows that they are facultative anaerobes, an observation similar to that of Eun-Kung et al., 2012; Saenz-Aponte et al.,(2014). Also formation of gas bubble upon addition of hydrogen peroxide was an indication of a positive test for catalase. The biochemical tests revealed that the isolate from Heterorhabditis bacteriophora had properties similar to described species for Photorhabdus bacteria. The isolate exhibited weak lecithinase and lipase activity and there was no production of proteases due to the absence of protein hydrolysis on the egg yolk agar. The weak activity is an indication of presence of phase II cells of Photorhabdus sp. whose activities are usually weak or completely negative for these enzymes when compared to phase I cells of Photorhabdus bacteria an 
observation shared with Burnell and Stock (2000). The isolate shares similar phenotypic and biochemical properties with that of described species of Photorhabdus luminescens. Pathogenicity test confirmed susceptibility of G. mellonella larvae to various concentrations of the bacterial isolate with $10^{6}$ $\mathrm{CFU} / \mathrm{ml}$ having the highest activity against the larvae within $48 \mathrm{~h}$. an observation similar to that of SaenzAponte et al., (2014). The pathogenicity test also confirms the biological control potential of the isolate against larvae of $G$. mellonella.

Conclusion: The bacterial endosymbionts were successfully isolated and characterized as Photorhabdus luminescens, however, there is a need for molecular characterization of the isolate in order to classify it to its sub-species level. The pathogenicity of the isolate against $G$. mellonella larvae was established; hence it's biological control potential against insect pests of agricultural produce can further be exploited. This report also serves as a baseline data for further research in this area.

\section{REFERENCES}

Aliyu, HU; Dahiru, M; Owuama, CI (2015) Isolation of Entomopathogenic Nematode-Bacteria Complex with a Potential for Use as a Biological Insecticide in Nigeria. J. Environ. Iss. Agric. Dev. Count. 7 (3):2141-2731

Aliyu, HU; Kela, SL; Agbo, EB; Tahir, F (2019). Isolation and determination of morphological characterization of heterorhabditid entomopathogenic nematodes (EPNs) from Kashere, Nigeria. EC Pham. Toxicol. J. 7 (12): 01-10

Adams, BJ; Fodor, A; Koppenhofer, HS; Stackebrandt, E; Stock, SP; Klein, MG (2006). Biodiversity and systematics of nematode-bacterium entomopathogens, Biol. Cont. 37: 32-49

Burnell, AM; Stock, SP (2000). Heterorhabditis, Steinernema and their bacterialsymbionts -lethal pathogens of insects. Nem. 2: $31-42$

Emeliahoff, V; Le-Brun, N; Pages, S; Stock, SP; Talliez, P; Moulia, C; Sicard, M(2008). Isolation and identification of entomopathogenic nematodes and theirsymbiotic bacteria from Herault and Gard (Southern France). J. invert.Path. 98:211-217

Eun-Kung,J; Ullah, I; Lim, JH; Lee, IJ; Kim, JG; Shin, JH (2012). Physiological and Molecular characterization of a newly identified entomopathogenic bacteria, Photorhabdus temperate M1021. Mcb. Biotech. 22:1605-1612
Ferreira, T; Van Reenan, C; Pages, S; Tailliez, P; Malan, AP; Dicks, LMT (2013).Photorhabdus luminescens subsp. noenieputensis subsp. nov., a symbiotic bacteriumassociated with a novel Heterorhabditis species related to Heterorhabditis indica.Int. J. Sys. Evol. Mcb. 63: 1853-1858.

Gaugler, R (2002). Entomopathogenic Nematology. CABI Publishing, New York,p. 388

Hinchliffe, SJ; Hares, MC; Dowling, AJ; ffrenchconstant, RH (2010). Insecticidaltoxins from Photorhabdus and Xenorhabdus bacteria. The Open Toxicol. J. 3: 101-118

Jang, E-K; Ullah, I; Kim, M-S; Lee, J-H; Shin, J-H (2011). Isolation andcharacterization of the Entomopathogenic bacterium, Photorhabdus temperateproducing a heat stable Insecticidal toxin. J.Plt diseas. Prot. 118 (5): 178-184.

Lang, A.E; Katharina, E; Lee,H ; Papatheodorou, P; Schwan, C; Barth, H; Aktories, K (2014). The Chaperone Hsp90 and PPlases of the Cyclophilin andFKBP Families Facilitate Membrane Translocation of Photorhabdus luminescens ADPribosyltransferases. C. Mcb. 16(4): 490-503.

Owuama, CI (2001). Entomopathogenic bacteria, Xenorhabdus and Photorhabdus of nematodes. W. J. Mcb. Biotech. 17: 505 - 515

Orozco, RA; Hill, T; Stock, SP (2013). Characterization and Phylogenetic relationships of Photorhabdussubsp. Sonorensis (y- proteobacteria: enterobacteriacaea), the bacterial symbiont of the Entomopathogenic Nematode Heterorhabditis sonorensis (Nematoda: Heterorhabditidae). Curr.Mcb.66: 30-39

Saenz-Aponte, A; Fabian, PO; Jaramillo, C (2014). Isolation and characterization of bacterial symbiont Photorhabdus luminescens SL0708 (Enterobacteriales: Enterobacteriaceae). Afr. J. Mcb. Res. 8(33): 3123-3130

Singh, S;Eric, M;Floyd, I; Leonard, HD (2012). Characterization of PhotorhabdusGrowth for the rearing of the beneficial nematode Heterorhabditis bacteriophora.Ind. J.Mcb52: 325-331

Webster, JM; Chen, G; Hu, K; Li, J; (2002). Bacterial metabolites. In: Gaugler R(ed) Entomopathoenic Nematology. CABI Publishing, Oxon, New York, p. 99-114. 